\title{
Cellular Changes in the Placenta in Pregnancies Complicated with Diabetes
}

\author{
Cambios Celulares en la Placenta en Embarazos Complicados con Diabetes
}

\author{
"Ranjana Verma; **Sabita Mishra \& *** Jagat Mohini Kaul
}

VERMA, R.; MISHRA, S. \& KAUL, J. M. Cellular changes in the placenta in pregnancies complicated with diabetes. Int. J. Morphol., 28(1):259-264, 2010.

SUMMARY: Placenta is the most accurate record of the infant prenatal experience. After delivery if the placenta is examined minutely, it provides much insight into the prenatal health of the baby and the mother. In diabetic pregnancy, placental weight is higher in comparison to normal pregnancy. To study the cellular differences that might contribute to larger size of placenta, light microscopic analysis was performed on 25 full term placentas, out of which 20 were of Gestational diabetes mellitus (12 controlled on diet, 8 controlled on insulin) and 5 control group. Tissue sections were processed and analyzed. Birth weight of neonate, placental weight, vascular pattern of chorionic blood vessels and site of attachment of umbilical cord were recorded. In the placenta of diabetic pregnants, gross abnormalities were uncommon but microscopic examination exhibited, to a varying degree, lesions like syncytial knots, fibrinoid necrosis, villous edema, villous fibrosis and capillary proliferation. These findings indicate that control of hyperglycemia only partially prevents the development of placental abnormalities which must be due to some other constituent factor of diabetic state.

\section{KEY WORDS: Placenta; Gross; Gestational diabetes; Microscopy.}

\section{INTRODUCTION}

Diabetes is now a major health concern in our society. According to the centers for disease control and prevention, from 1980 to 2005, the crude incidence of diagnosed diabetes increased $124 \%$ from 3.3 per 1000 to 7.4 per 1000 . Studies suggest that the prevalence of diabetes mellitus (DM) among women of childbearing age is increasing due to more sedentary lifestyles, changes in diet, and the virtual epidemic of childhood and adolescent obesity that is presently evolving in our country. Gestational diabetes mellitus (GDM) is defined as glucose intolerance of variable degree with onset or first recognition during pregnancy. Abnormal maternal glucose tolerance occurs in 3-10\% of pregnancies (Dutta, 2004).

The diabetic pregnancy is characterized by numerous disturbances in the fetal growth and development. Fetal macrosomia, congenital malformations and intrauterine growth retardation are commonly seen in poorly controlled diabetes (Fletcher, 1981). The placenta in pregnancy complicated with diabetes is generally larger than normal and has numerous structural abnormalities that are likely to have a role, resulting in disturbances of fetal growth and development (Singer, 1984). In an attempt to explain discrepancy between the fetal size and placental size and to explore disparities between the placental size and apparent functioning of the placenta in the diabetic pregnancy, the study of microscopic structure of placenta is significant (Gewolb et al., 1986).

Some workers have claimed that placentas from diabetic women show no unusual feature while others have observed frequent abnormalities in such placentas but failed to agree on any consistent pathologic pattern. The placenta of diabetic pregnants have shown villous lesions on light microscopy, such as excess syncytial knot formation (Burstein et al., 1957; Clavero-Nunez, 1963; Dashkevich \& Sechenov, 1964), increased thickness of vasculosyncytial membrane (Burstein et al., 1963; Holzner \& Thalhammer, 1965), villous fibrinoid necrosis (Burstein et al., 1957; Sani et al., 1964), villous immaturity (Horky, 1964; Hughes, 1961)

* Assistant Professor. Department of Anatomy, Maulana Azad Medical College, India.

** Professor. Department of Anatomy, Maulana Azad Medical College, India.

*** Director Professor \& Head of Department. Department of Anatomy, Maulana Azad Medical College, India. 
and abnormalities of villous vascularisation (Clavero-Nunez; Horky, 1964; Horky, 1965;) but others have failed to reveal any of these abnormalities. This confusion is partly due to the inclusion, in many studies, of gestational diabetes mellitus (GDM) in whom there was either superadded preeclamptic toxemia or intrauterine fetal death; as these complications may obscure the significance of diabetic placentas. It is therefore not surprising that the result obtained have been inconsistent and indeed, often contradictory (Jones \& Fox, 1976).

Studies of placentas from diabetic pregnancies, in which these complicating factors will be excluded, may yield a moderately consistent pattern of abnormalities at microscopic levels which may not be specific, yet characteristic. The pathogenesis of these abnormalities is still far from being fully understood but there is a widespread impression that their extent and degree are related not only to the severity and duration of the maternal diabetes mellitus but also to the degree of control of the diabetic condition during pregnancy. If this is indeed the case, then the placenta of the woman with mild gestational diabetes or extremely well controlled overt gestational diabetes should either show no abnormality or only minimal changes. It is this assumption that we have examined in this study.

\section{MATERIAL AND METHOD}

Twenty five placentas of full term pregnancy were collected from labour room, LNJP Hospital, New Delhi. The range of age of these mothers varied from 20 years to 38 years and the parity from 1 to 5 .

The total number of placentas from diabetic pregnant (GDM) was twenty and in all cases the degree of control achieved was considered to be excellent whether controlled by diet alone or by insulin. Five control placentas of normal pregnancy were without any known pre - existing disease or its complications (Table I). All the patients delivered either by vaginal route or by caesarian section.

Table I. Showing total number of placentas studied from case and control group.

\begin{tabular}{llc}
\hline & & $\begin{array}{c}\text { Number of } \\
\text { placentas }\end{array}$ \\
\hline Control & Controlled on diet & 5 \\
Gestational Diabetes & 12 \\
mellitus (GDM) & Controlled on insulin & 8 \\
\hline
\end{tabular}

Gross observation of placentas was done and following points were noted.
-Weight of placenta

-Fetal weight was noted in the labour room

-The site of attachment of umbilical cord

-Vascular pattern of the chorionic blood vessels of placenta

For light microscopy, two $\mathrm{cm}$. wedge of tissue was taken from the centre of each placenta and fixed in $10 \%$ formalin for one week. The tissue was dehydrated and followed by embedding in paraffin and 7 micron serial sections were generated with the help of rotatory microtome. The tissue sections were stained with hematoxylene and eosin. Histological appearance of the terminal villi of placentas was assessed and following observations were made.

Trophoblast:The number and position of syncytiotrophoblast, syncytial knots and cytotrophoblast nuclei was assessed (Jones \& Fox, 1977).

Villous stroma: The density of villous stroma was assessed qualitatively by looking for the presence of collagen fibres, and density of the background fibrillar material (Castellucci \& Kaufmann, 1982; Jones \& Fox, 1991).

Fetal capillary:Evidence of capillary proliferation and obstruction within the capillary lumen was sought in each case.

\section{RESULTS}

Gross observation. The gross findings are summarized in the Table II. No obvious difference was identified in the fetal weight and placental weight between the placentas of diabetic group and control group. The linear relationship between the fetal weight and the placental weight was also maintained. The dispersal vascular pattern (Fig. 1) of the chorionic blood vessels of the placenta was more frequent in the GDM controlled on the diet and control group while magistral pattern (Fig. 2) was more common in the GDM controlled on insulin. Site of umbilical cord insertion was eccentric or central in all placentas except one in which it was marginal.

Light microscopy. The light microscopic findings are summarized in the Table III. The terminal villi in placentas of diabetes controlled on insulin showed a varying degree of changes like, the increased number of syncytial knots (Fig.3). The stroma of the villi demonstrated villous edema (Fig. 4) in two placentas, and fibrinoid necrosis (Fig. 5) was present in five placentas. Villous fibrosis (Fig. 6) and foetal capillary proliferation (Fig. 7) was observed in one placenta 
each. By contrast, the placentas of diabetes controlled on diet, showed minimal changes in the terminal villi (more number of syncytial knots, fibrinoid necrosis in some ca- ses), resembling more to the control placenta. In none of the placentas of GDM controlled on diet showed villous edema, villous fibrosis or fetal capillary proliferation.

Table II. Gross observation of placenta.

\begin{tabular}{llccc}
\hline & & Control (5) & $\begin{array}{c}\text { GDM controlled } \\
\text { on (diet) - (12) }\end{array}$ & $\begin{array}{c}\text { GDM controlled } \\
\text { on (insulin) - (8) }\end{array}$ \\
\hline Placental weight & & 517 & 538 & 520 \\
Fetal weight (kg) & Male & 2.99 & 3.048 & 3.28 \\
& Female & 2.54 & 3.025 & 2.97 \\
Vascular pattern & Dispersal & 3 & 9 & 2 \\
& Magistral & 2 & 3 & 6 \\
Site of umbilical & Eccentric \& central & 5 & 11 & 8 \\
cord attachment & Marginal & - & 1 & - \\
\hline
\end{tabular}

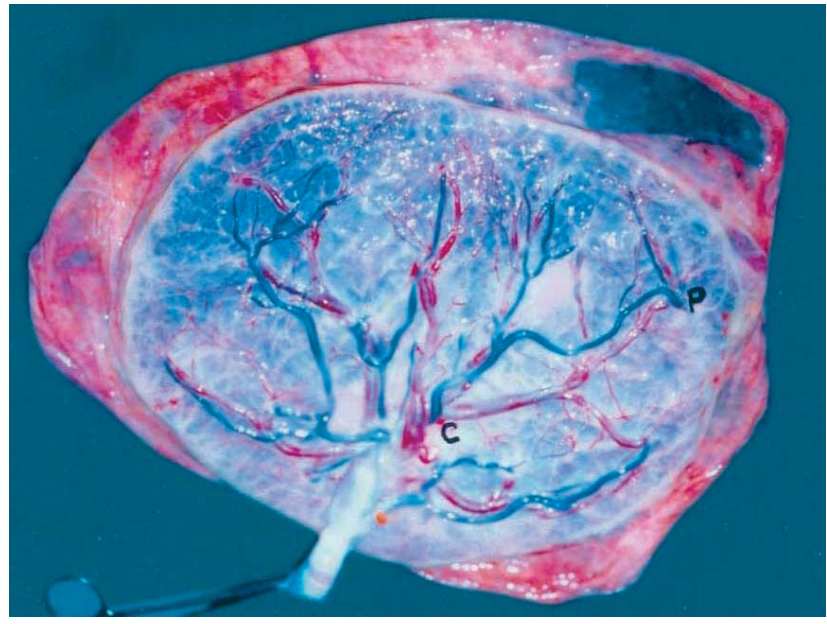

Fig. 1. Vascular pattern of placenta.

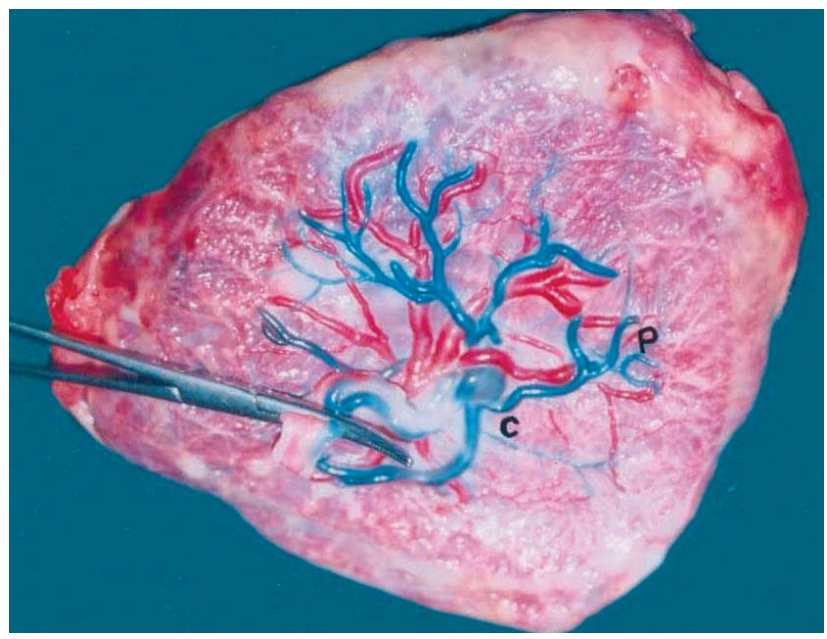

Fig. 2. Vascular pattern of placenta.

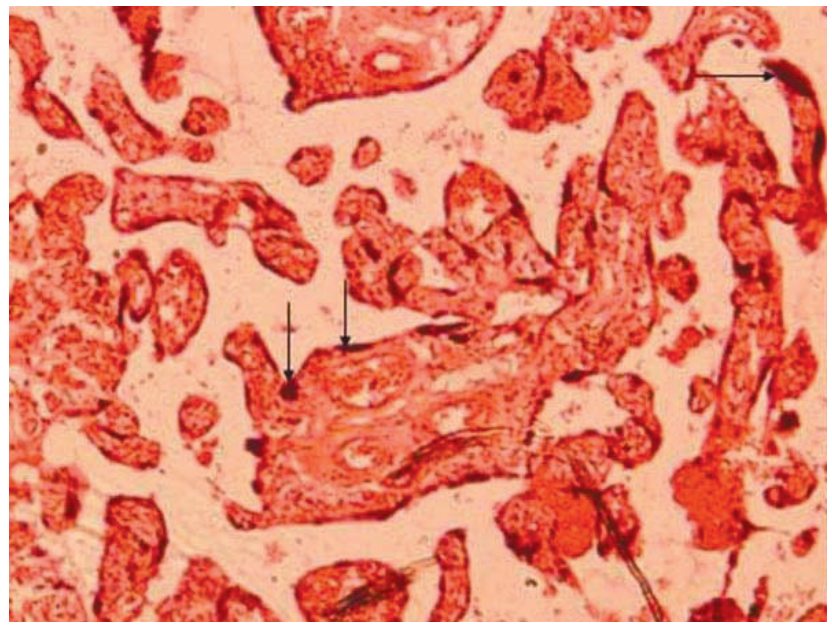

Fig. 3. Arrow marked areas of syncytial knot formation. $\mathrm{H} \& \mathrm{E}$ $40 \mathrm{X}$.

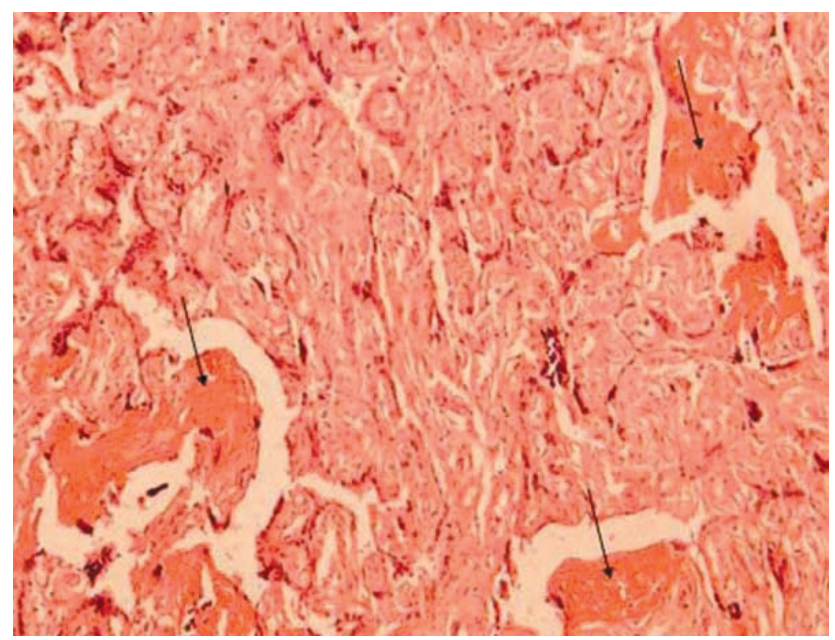

Fig. 4. Arrow marked areas of fibrinoid necrosis and congestion of villi. H \& E 40X. 
Table III. Light microscopic structure of terminal villi.

\begin{tabular}{|c|c|c|}
\hline Control (5) & $\begin{array}{l}\text { GDM controlled on } \\
\text { (diet) - (12) }\end{array}$ & $\begin{array}{l}\text { GDM controlled on } \\
\text { (insulin) - (8) } \\
\text { More svncytial knots }\end{array}$ \\
\hline Visible & $\begin{array}{l}\text { More } \\
\text { syncytial knots }\end{array}$ & More syncytial knots \\
\hline Scanty & More & More \\
\hline Connective tissue elements & $\begin{array}{l}\text { Mild edema } \\
\text { Fibrinoid necrosis }\end{array}$ & $\begin{array}{l}\text { Edema prominent } \\
\text { Fibrinoid necrosis } \\
\text { Villous fibrosis }\end{array}$ \\
\hline- & - & $\begin{array}{l}\text { Capillary } \\
\text { proliferation more }\end{array}$ \\
\hline
\end{tabular}

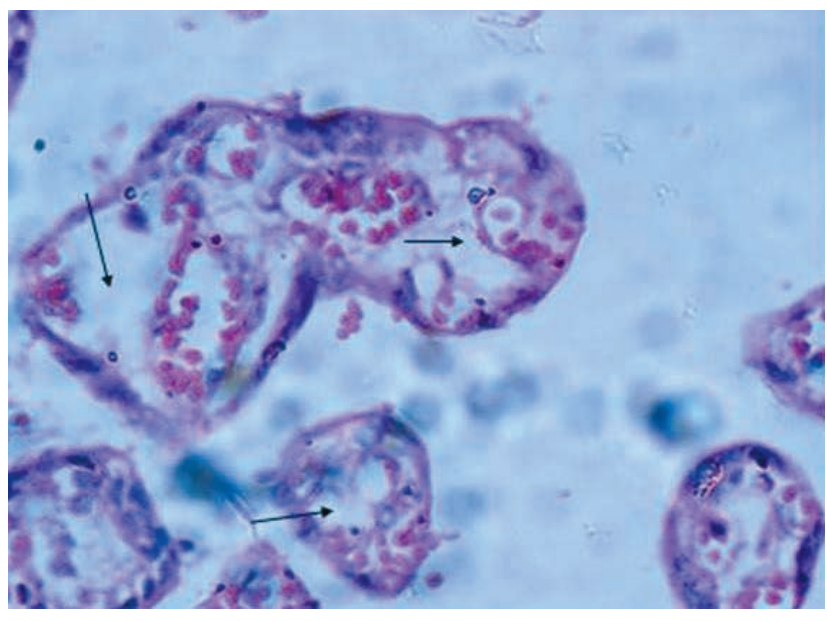

Fig. 5. Arrow marked areas of villous edema. H \& E 40X.

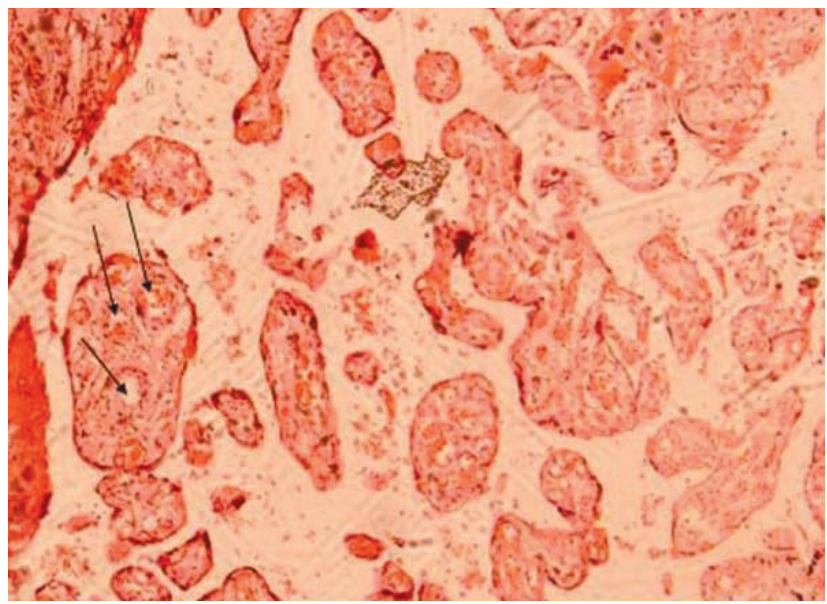

Fig. 7. Arrow marked areas of capillary proliferation. H \& E 40X.

\section{DISCUSSION}

The longitudinal alteration in the maternal metabolism during pregnancy with normal glucose tolerance, provide both maternal and fetal-placental growth and energy

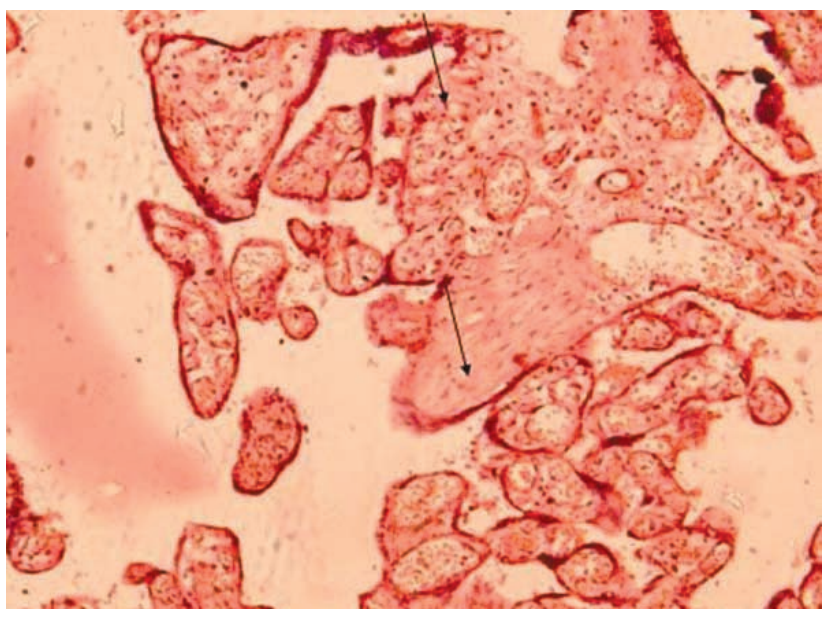

Fig. 6. Arrow marked areas of villous fibrosis. H \& E 40X.

requirements. There are major adaptations in the maternal metabolism throughout pregnancy that result in increased fat stores in early pregnancy and increased availability of protein and carbohydrate in late pregnancy. In female with diabetes, there is previous abnormality in carbohydrate metabolism and possibly protein and lipid metabolism (Patric et al., 1996). These biochemical changes occurring during pregnancy would be reflected on the placental structure.

Reports on the pathology of placenta in diabetes mellitus are numerous but often contradictory. The inconsistency may be explained in part, by the fact that the category of diabetic pregnant women is very heterogeneous. The delineation of placental lesions in maternal diabetes has been also made unduly complex by the superimposed hypertensive and other associated complications. In the present study, complicating factors were excluded, and the degree of control of diabetes was considered to be excellent.

In our study, on gross observation, there was no major difference in the placenta of diabetic group and control group. The weight of placenta and fetus in pregnancies complicated 
with diabetes was similar as compared to the control group and linear relationship was also maintained between fetal and placental weight at term. However, in only one case of GDM controlled on insulin, weight of placenta was more than $800 \mathrm{gms}$ and fetal weight was $4.34 \mathrm{~kg}$. These observations are in agreement with a recent study in which the mean weights were similar in diabetic and control group (Mayhew et al., 1994). Previous studies have shown that the many placentas are essentially normal, although in more than half, the placenta was larger, heavier and thicker than control group of the same gestational age (Aladjem, 1967). In another study, it was observed that the placental weight and neonatal weight were increased, provided the diabetes was not complicated with vascular disease (Maksheed et al., 2002). It was also noted that the linear relationship between fetal weight and placental weight documented throughout pregnancy and also at birth, correlated well (Abramovich, 1969).

The dispersal vascular pattern of chorionic blood vessels of placenta was more frequently observed in the placentas of GDM controlled on diet and also in control group while magistral pattern was more common in the placentas of GDM controlled on insulin. Usually, the dispersal vascular pattern the chorionic blood vessels of placenta was more frequent than the magistral pattern. The site of attachment of Umbilical cord Eccentric or central is most of the placentas except in one case in which there was marginal insertion of placenta.

Several differences were identified in the light microscopy of terminal villi from the placentas of GDM controlled on insulin; large number of syncytial knots, fibrinoid necrosis, villous edema, villous fibrosis and proliferation of the capillaries while placentas of GDM controlled on diet showed increased number of syncytial knots and fibrinoid necrosis, but to lesser extent, resembling more to the control group. Some workers have claimed that placentas of diabetic women show no unusual features (Cardwell, 1953). Increased number of syncytiotrophoblast nuclei were noted in the placentas of GDM. These nuclei showed chromatin clumping, a feature typical of senescence, and were usually arranged in clusters known as syncytial knots (Jone \& Fox, 1977). There was a report of villous immaturity, proliferation of small fetal vessels \& Syncytial knots in diabetic placentas (Yang, 1993). Another study has revealed fibrin thrombi, villous edema, hyperplasia and thickening of basal membrane of trophoblast in the placenta of poorly controlled diabetes (al-okail \& al-Attas, 1994). Furthermore studies, showed no major difference in the microscopic changes of placentas in different groups according to White's classification and the normal group (Maksheed et al.).

All these abnormalities were not present in every placenta but they were not completely absent in any. Each of these abnormalities may also be seen, but to a much more limited extent in placentas from GDM controlled on diet. It should be noted that there was no correlation in this series between the severity of placental changes and the weight of the fetus and placenta but the placenta of women receiving insulin showed more placental changes on microscopic examination as compared to those whose blood sugar was controlled by diet alone. This being the case, it would be logical to assume that the less severe and better controlled the patients diabetic state, the less striking would be the placental abnormalities. The present study also indicates that such changes still occur to an unpredictable degree, in women with diabetic disturbance is of an extremely mild and transient type that is easily and excellently controlled. Hence, elimination of hyperglycemia will not in itself prevent the development of placental abnormalities, and these must be due to some unknown constitue factor of the diabetic state which is only partially influenced by the diet or insulin.

VERMA, R.; MISHRA, S. \& KAUL, J. M. Cambios celulares en la placenta en embarazos complicados con diabetes. Int. J. Morphol., 28(1):259-264, 2010.

RESUMEN: La placenta es el registro más preciso de la experiencia prenatal infantil. Después del parto, si la placenta se examina minuciosamente, esta proporciona una visión de la salud prenatal del bebé y la madre. En el embarazo con diabetes, el peso de la placenta es mayor en comparación con el embarazo normal. Para estudiar las diferencias celulares que podrían contribuir al mayor tamaño de la placenta, se realizó el análisis en microscópico de luz en 25 placentas de término, de las cuales 20 fueron diabetes mellitus gestacional (12 controladas por dieta, 8 controlodas por insulina) y 5 del grupo control. Los cortes fueron procesados y analizados. El peso al nacer de los recién nacidos, el peso de la placenta, el patrón vascular de los vasos sanguíneos coriónicos y el lugar de inserción del cordón umbilical fueron registrados. En la placenta de las embarazadas con diabetes, alteraciones graves fueron poco frecuentes, pero el exámen microscópico mostró, en grado variable, lesiones como nudos sincisiales, necrosis fibrinoide, edema de las vellosidades, vellosidades fibrosas y proliferación capilar. Estos resultados indican que el control de la hiperglucemia sólo en parte impide el desarrollo de anormalidades de la placenta las cuales deben producirce por algún otro factor constituyente del estado diabético.

PALABRAS CLAVE: Placenta; Macroscópica; Microscópica; Diabetes gestacional. 


\section{REFERENCES}

al-Okail, M. S. \& al-Attas, O. S. Histological changes in placental syncytiotrophoblast of poorly controlled gestational diabetic patients. Endocr. J.; 41(4):355-60, 1994.

Abramovich, D. R. The weight of placenta and membranes in early pregnancy. J. Obstet. Gynaecol. Br. Commonw., 76(6):523-6, 1969.

Aladjem, S. Morphologic aspects of the placenta in gestational diabetes seen by phase-contrast microscopy. An anatomicoclinical correlation. Am. J. Obstet. Gynecol., 99(3):341-9, 1967.

Burstein, R.; Bernes, A. W.; Hirata, Y. \& Blumenthal, H. T. A comparative histo- and immunopathological study of the placenta in diabetes mellitus and in erythroblastosis fetalis. Am. J. Obstet. Gynecol., 86:66-76, 1963.

Burstein, R.; Soule, S. D. \& Blumenthal, H. T. Histogenesis of pathological processes in placentas of metabolic disease in pregnancy. II. The diabetic state. Am. J. Obstet. Gynecol., 74(1):96-104, 1957.

Cardwell, B. S. The infants of diabetic mothers; a morphological study. J. Obstet. Gynaecol. Br. Emp., 60(6):834-53, 1953.

Castellucci, M. \& Kaufmann, P. A three dimensional study of the normal human placental villous core II Stromal architecture. Placenta, 3(3):269-85, 1982.

Clavero-Nunez, J. A. The placenta in diabetes. Rev. Iber. Endocrinol., 10:73-80, 1963.

Dashkevich, O. V. \& Sechonov, I. M. The morphology of placenta in diabetes mellitus. Arkh. Pat., 26:7, 1964.

Dutta, D. C. Medical and surgical illness complicating pregnancy. In: Text Book of Obstetrics. $6^{\text {th }}$ Ed. Calcutta, New Central Book Agency (P) Ltd., 2004. pp.284-90.

Fletcher, A. B. The infant of diabetic mother. In: Neanatology Pathophysiology and Management of the Newborn. Philadelphia, Lippincott, 1981. pp.287-302.

Gewolb, H.; Merdian, W.; Warshaw, J. B. \& Enders, A. C. Fine Structural Abnormalities of the Placenta in Diabetic Rats. Diabetes, 35(11):1254-61, 1986.

Holzner, H. J. \& Thalhammer, O. Zur Histologie und Histochemie der Placenta bei Diabetes Mellitus und Schwangerschaftglykosurie. Wein Klin. Wschr., 77:1024, 1965.
Horky, Z. Die quantitativen veranderungen der Vaskularisation der Zotten in der diabetischen Placenta. Zbl. Gynaek., 86:8, 1964.

Horky, Z. Die Reifungstorungen der Placenta bei Diabetes Mellitus. Zbl. Gynaek., 87:1555, 1965.

Hughes, E. C. The placenta as it applies to the practice of obstetrics. South Med. J., 54:610-9, 1961.

Jones, C. J. \& Fox, H. Ultrastructure of the normal human placenta. Electron. Microsc. Rev., 4(1):129-78, 1991.

Jones, C. J. \& Fox, H. Placental changes in gestational diabetes. An ultrastructural study. Obstet. Gynecol., 48(3):274-80, 1976.

Jones, C. J. \& Fox, H. Syncytial knots and intervillous bridges in the human placenta: an ultrastructural study. J. Anat., 124(Pt 2):275-86, 1977.

Marksheed, M.; Musini, V. M.; Ahmed, M. A. \& Al-Harmi, J. Placental pathology in relation to the White,s classification of diabetes mellitus. Arch. Gynecol. Obstet., 266(3):13640, 2002.

Mayhew, T. M.; Sorensen, F. B.; Klebe, J. G. \& Jackson, M. R. Growth and maturation of villi in placentae from wellcontrolled diabetic women. Placenta, 15(1):57-65, 1994.

Patric, M. C.; Mark, B. L. \& Steven, G. Diabetes Mellitus. In: Reproductive endocrinology, surgery and technology. Piladelphia, Lippincott, 1996. pp.1710-20.

Sani, G. \& Bottigliani, F. Studio isto fungionale della placenta nel diabete mellito. Riv. Ital. Ginec., 48:283, 1964.

Singer, D. B. The placenta in pregnancies complicated by diabetes mellitus. Perspect. Pediatr. Pathol., 8:199-212, 1984.

Yang, H. X. Placental pathology in gestational diabetes. Zhonghua Fu Chan Ke Za Zhi, 28(12):714-6, 1993.

\author{
Correspondence to: \\ Jagat Mohini Kaul \\ Department of Anatomy \\ Maulana Azad Medical College \\ New Delhi-110002 \\ INDIA
}

Received: 14-05-2009

Accepted: 25-11-2009 